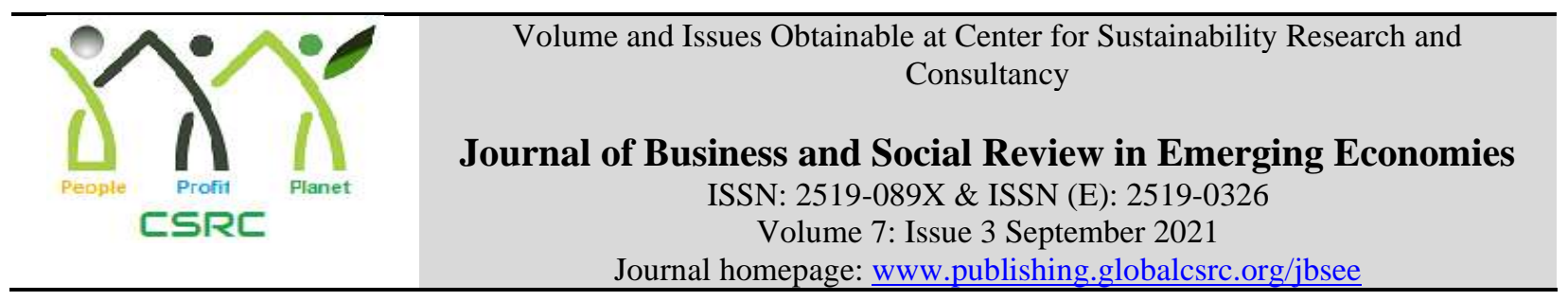

\title{
Sectoral Investment and Trade in Pakistan: An Empirical Analysis
}

Furrukh Bashir, School of Economics, Bahauddin Zakariya University, Multan, Pakistan Salyha Zulfiqar Ali Shah, School of Economics, Bahauddin Zakariya University, Multan, Pakistan

*Rashid Ahmad, School of Economics, Bahauddin Zakariya University, Multan, Pakistan

Tayyaba Naveed, School of Economics, Bahauddin Zakariya University, Multan, Pakistan

*Corresponding author's email: rashidahmad@bzu.edu.pk

\begin{tabular}{l}
\hline ARTICLE DETAILS \\
\hline History \\
Revised format: Aug 2021 \\
Available Online: Sep 2021 \\
\hline Keywords \\
Sectoral Investment, \\
Agriculture, ARDL, \\
Pakistan \\
\hline
\end{tabular}

JEL Classification

$F 1, F 10$

\begin{abstract}
Purpose: This study is conducted to examine the effectiveness of Investment in various sectors of the economy on exports of Pakistan over the period from 1972 to 2018.

Methodology: For this purpose, World Development Indicators and Handbook of Statistics on Pakistan Economy have been utilized to collect time-series data on the related variables. Moreover, the econometric results have been calculated using the ARDL approach and diagnostics statistics are based on Normality Test, Ramsey RESET test and stability tests.

Findings: The long-run results explore that Investments in the Agriculture \& Manufacturing sectors, Terms of Trade and Human Capital are increasing exports of Pakistan while investments in Services \& Transportation sectors are reducing exports of Pakistan.

Implications: Based on econometric results, it is suggested that investments in manufacturing and agriculture sectors should be enhanced through low interest rates or by providing opportunities to the private sector so that it may lead to higher growth and exports.
\end{abstract}

(C) 2021 The authors, under a Creative Commons AttributionNonCommercial 4.0

Recommended citation: Bashir, F., Shah, S. Z. A., Ahmad, R. and Naveed, T. (2021). Sectoral Investment and Trade in Pakistan: An Empirical Analysis. Journal of Business and Social Review in Emerging Economies, 7 (3), 801-808.

\section{Introduction}

Sectoral investment is seen as an essential component in determining a country's trading pattern. Investment in various areas may result in an increase or decline in the country's economic performance. In numerous researches, the impact of inward and outward FDI on trade has been analyzed for econometric analysis. However, the current study examines the impact of sectoral investment on Pakistan's trade. Pain et al. (1997) studied the relationship between the location and trade of 11 different OECD nations. The results of the study have revealed that the previous year's relative price, lagged exports and product price all had a negative relationship with the trade. The 
study also concluded that the previous year's global demand, previous year's product quality and measure of global demand show a significant influence on the exports. It was also observed that but inward and outward foreign direct investment present both ways (positive and negative) relation with the exports.

Pain et al. (1998) studied the cross-sectional data of 11 OECD countries, during the period between 1971-1992. The authors stated that the countries under investigation have argued for the standard export demand model, which involves market size, relative prices, measures of relative innovation, inward and outward investment levels. The findings of the study conclude that elasticity demand and quality show a positive influence on the prices and export, in the long run. However, a positive as well as a negative association between inward foreign direct investment and exports.

Marchant et al. (1999) have analyzed the annual data to investigate the impact of US foreign direct investment and processed food exports to China. Moreover, this study has attempted to suggest managerial measures to improve and promote US competitiveness. The authors have collected secondary data from the FATUS calendar year report regarding the export and export prices of processed food to China. According to the result of the study, a significant association between foreign direct investment and exports has been found. It was also concluded that a negative relationship is present between the exports and export prices

Wongpit (2006) examined the impact of foreign direct investment on exports performance by analyzing different source countries (Japan, USA, China, EU, Singapore, etc) to Thailand using panel data from 1990 to 2010. The results of OLS show that exports are positively related to the gross domestic product, foreign direct investment, and dummy variables. The study also revealed that distance, import tariff, and the real bilateral exchange rate are negatively related to exports. According to the findings, foreign direct investment from the source nations. support manufacturing exports to Thailand.

Vukic (2006) investigated the impact of inflows on export performance, after controlling for other potentially significant variables. The study examined panel data from EU countries (especially those in Central and Eastern Europe) during the period from 1996 to 2002. The study found a positive association between productivity, real effective exchange rate, investment, and foreign direct investment. The study also concluded that a negative relationship is present between exports and unit labor cost.

Kutan et al. (2007) collected data from central and eastern European economies (CEE). The authors collected secondary pooled data for the year 1996-2004. It was concluded from the results that a positive relationship between exports and gross domestic product, real exports, and FDI stock in all countries.

Cuyvers et al. (2008) examined data from 1994 to 2005 in Cambodia. The study found that real gross domestic product, real per capita gross domestic product, real exchange rate, foreign direct investment, and the presence of trade agreement all had a positive relationship with exports. It was also concluded that the duration of China's WTO membership had a negative relationship.

Bhutto et al. (2008) has collected annual data during the period from 1977 to 2005 of FDI and exports in Pakistan. The author has collected data from the State Bank of Pakistan's (SBP) statistical database. The main focus of the study was to determine the overall macroeconomic impact and indirect impact of foreign direct investment on the country's exports.

According to Abdul et al. (2010), a positive association was found between foreign direct investment, GDP, and imports. Furthermore, the results of the present study revealed that a negative 
association between relative pricing and imports of the country. The results of the study also revealed that in Pakistan, there is a considerable positive short-run relationship between foreign direct investment and imports.

Hailu (2010) examined the relationship between foreign direct investment and trade balance in and African countries. The author had collected annual data from 1980 to 2007 years. It was concluded from the results that a negative effect exists between the real effective exchange rate and imports. Moreover, there was a significant correlation between infrastructure, previous year's exports, previous year's imports, and trade. The study found that Imports, world income, and trade all have a negative association with the actual effective exchange rate.

Rahman (2011) collected time-series data from 1972 to 2007 in Bangladesh. The author collected data during the period 1980 and 2009, using the World Bank's world development index. The findings of the study conclude that foreign direct investment causes imports, but that there was no causal relationship between exports and foreign direct investment. Adhikary (2012) examined the impact of foreign direct investment, trade openness, local demand, and the exchange rate on Bangladesh's export performance. The study's findings revealed that the domestic capital, foreign direct investment, trade openness, exchange rate, and export performance in Bangladesh, have a long-term relationship.

Goswami et al. (2012) studied the current status of foreign direct investment and exports in the North-East Region (NER). The authors collected annual data from the Reserve Bank of India for a duration of 20 years, from 1991 to 2010 . The results of the study show that the relationship among dependent and independent variables was investigated using the vector error correction model (VECM). Foreign direct investment and exports were found to have bi-directional causality, according to the study.

Nishitateno (2012) used panel data to assess 37 commodities and 49 host economies, from 1999 to 2008. The findings revealed a positive relationship between exports, gross domestic product, GDP per capita, nominal exchange rate and production. Moreover, it was also revealed that there was a negative relation between exports and overseas operations and the distance.

Bhatt (2013) has collected data from the International Monetary Fund and UNCTAD, from the year 1978-2009 in China. The author has attempted to examine the different dimensions of foreign direct investment in China. The authors study the causal relationship between exports, gross domestic product and foreign direct investment. The study concluded that there was a positive relationship between gross domestic product, exports and foreign direct investment.

Pourshahabi et al. (2013) used panel data from 16 advanced European countries, during the period from 1976 to 2008. The study looked at the long-run and short-run causal relationship between FDI, exports, imports, and overall trade. The findings revealed that exports and imports had a favorable and significant impact on foreign direct investment. this results in accelerating trade openness and increased foreign direct investment. The short-run causality between variables was bidirectional, but the long-run causality ran from import and export to foreign direct investment.

Goh et al. (2013) used panel data from 1991 to 2009 to study foreign direct investment. The authors have adopted employed econometric model to investigate the relationship between inward trade and outward foreign direct investment in Malaysia. Simionescu (2014) investigated the long-run and short-run causation between foreign direct investment, imports, exports, and trade in G7 countries. The authors collected the data during the period from period 2002-2013 year for the econometric analysis. 
Selimi et al. (2016) analyzed the foreign direct investment and export performance from 1996 to 2013 in Western Balkan countries. Results of the study show that there was a positive relationship between exports, gross fixed capital formation and industry value added as a proportion of GDP.

Stojcic et al. (2016) used the data from countries from 2007-2015, to study the influence of foreign direct investment on exports in OECD and BRIC economies. The findings of the study revealed the positive influence of on exports.

Asirvatham et al. (2017) collected panel data to investigate the determinants of trade in the founding five ASEAN countries. The study used fixed and random effects to examine the relationship between the dependent and independent variables. The study found a positive association between foreign direct investment and imports and exports, but a negative relationship between tariffs and exports.

Rafat (2017) investigated the relationship between trade integration and foreign direct investment in Iran. The finding of the study concludes that exports had a positive association with gross domestic product and openness. The results of the study showed a negative relationship with the real exchange rate.

Zhanje et al. (2018) examined the impact of foreign direct investment on export performance in Zimbabwe. The authors while controlling for other factors including economic growth and trade. Time-series data were collected from 1980 to 2016 using the Word Bank database. Exports and foreign direct investment were found to have a positive relationship in the economy.

\section{Data and Methodology \\ Data Description}

The objectives of the study are fulfilled by taking time series data ranging from 1972 to 2018 and it is extracted from World Development Indicators managed by the World Bank and Handbook of Statistics on Pakistan Economy. The data on agriculture, manufacturing, services sector and transport are taken in million rupees while the term of trade and human capital are in index numbers. The Econometric results are measured using the Autoregressive and Distributed Lag Model and a few diagnostic statistics.

\section{Model Specification}

Considering the objective of the study, following model is specified in equation form; $T R A D E=\alpha_{\circ}+\beta_{1} A G R I+\beta_{2} M A N U+\beta_{3} S E R V+\beta_{4} T O T+\beta_{5} H U M C A P+\beta_{6}$ TRANS $+\mu_{i}$

Where TRADE is the dependent variable which is exports of goods and services, AGRI is an investment in the agriculture sector, MANU is an investment in the manufacturing sector, TRANS is an investment in the transport sector, SERV is an investment in the services sector, TOT is terms of trade and HUMCAP is the human capital index.

\section{Results and Discussion}

The detail of result of the Unit Root test is provided in table 1 which shows that Trade, investments in agriculture, manufacturing, transportation \& services sector and human capital are stationary at $1^{\text {st }}$ difference while the term of the trade is stationary at a level so ARDL may be applied for econometric results.

Table 1: Augmented Dickey-Fuller test

\begin{tabular}{|c|c|c|c|}
\hline Variables & Unit Root Conducted at & Probability Values & Conclusion \\
\hline Trade of Goods & Level with Intercept & 0.50 & \multirow{2}{*}{$\mathrm{I}(1)$} \\
\cline { 2 - 3 } and Services & Level with Trend and Intercept & 0.63 & \\
\cline { 2 - 3 } & $1^{\text {st }}$ difference with Intercept & 0.00 & \\
\hline
\end{tabular}




\begin{tabular}{|c|c|c|c|}
\hline \multirow{3}{*}{$\begin{array}{l}\text { Investment in } \\
\text { Agriculture } \\
\text { sector }\end{array}$} & Level with Intercept & 0.73 & \multirow[t]{3}{*}{$\mathrm{I}(1)$} \\
\hline & Level with Trend and Intercept & 0.44 & \\
\hline & $1^{\text {st }}$ difference with Intercept & 0.00 & \\
\hline \multirow{3}{*}{$\begin{array}{c}\text { Investment in } \\
\text { Manufacturing } \\
\text { sector }\end{array}$} & Level with Intercept & 0.18 & \multirow[t]{3}{*}{$\mathrm{I}(1)$} \\
\hline & Level with Trend and Intercept & 0.61 & \\
\hline & $1^{\text {st }}$ difference with Intercept & 0.00 & \\
\hline \multirow{2}{*}{$\begin{array}{l}\text { Investment in } \\
\text { Services sector }\end{array}$} & Level with Intercept & 0.98 & \multirow[t]{2}{*}{$\mathrm{I}(0)$} \\
\hline & Level with Trend and Intercept & 0.00 & \\
\hline \multirow[t]{3}{*}{ Terms of Trade } & Level with Intercept & 0.90 & \multirow[t]{3}{*}{$\mathrm{I}(1)$} \\
\hline & Level with Trend and Intercept & 0.59 & \\
\hline & $1^{\text {st }}$ difference with Intercept & 0.00 & \\
\hline \multirow[t]{4}{*}{ Human Capital } & Level with Intercept & 0.65 & \multirow[t]{4}{*}{$\mathrm{I}(1)$} \\
\hline & Level with Trend and Intercept & 0.37 & \\
\hline & $1^{\text {st }}$ difference with Intercept & 0.17 & \\
\hline & $1^{\text {st }}$ difference with Trend and Intercept & 0.08 & \\
\hline \multirow{3}{*}{$\begin{array}{c}\text { Investment in } \\
\text { transportation } \\
\text { sector }\end{array}$} & Level with Intercept & 0.58 & \multirow[t]{3}{*}{$\mathrm{I}(1)$} \\
\hline & Level with Trend and Intercept & 0.23 & \\
\hline & $1^{\text {st }}$ difference with Intercept & 0.07 & \\
\hline
\end{tabular}

Table 2 shows the outcome of the ARDL bound testing approach applied to examine the existence of longrun relationship between variables used in this study. The F-statistics value is 5.45 reflecting existence of cointegrating-longrun relationship between variables used in the model.

Table 2: ARDL Bound test

\begin{tabular}{|c|c|c|}
\hline Test Statistic & Value & K \\
\hline F-Statistic & $5.45^{*}$ & 6 \\
\hline
\end{tabular}

* At 1 percent, $\mathrm{I}(1)$ Bound $=4.43$ and $\mathrm{I}(0)$ Bound $=3.15$

The long-run estimates of the exports model are reported in table 3 in which coefficients and probability values are given. Investment in Agriculture Sector and Investment in Manufacturing Sector are turned out to be significant and positively related with Trade of Pakistan in the long run. There is less elastic effect of Investment in Agriculture sector on Trade while Investment in Manufacturing sector is having more elastic effect on trade in the longrun. The results may be justified as agriculture sector is providing raw material to the trade sector that's why its effect on trade is less elastic while manufacturing sector provides the fully furnished goods to the trade sector having more elastic effect on trade in the long run.

On the other side, the results of terms of trade and human capital are also positively contributing the trade of Pakistan in the long run. The effect of Human Capital on Trade is more elastic while impact of terms of trade on trade is insignificant. Improved Human Capital may enhance productive capacity, GDP growth and trade of Pakistan. Investment in Services Sector and Investment in Transportation Sector are significant factors of reducing trade of Pakistan in the long run. Improving services sector may not have appropriate results on trade as of manufacturing sector. Due to poor transportation facilities in developing countries, the effect of transportation sector is negative with trade.

Table 3: Long Run Coefficients
\begin{tabular}{|c|c|c|c|c|}
\hline Variables & Coefficient & Standard Errors & t-Statistics & Probability \\
\hline Investment in Agriculture Sector & 0.2686 & 0.1387 & 1.9364 & 0.072 \\
\hline Investment in Manufacturing Sector & 1.0537 & 0.3728 & 2.8263 & 0.013 \\
\hline Investment in Services Sector & -0.4465 & 0.0986 & -4.5282 & 0.000 \\
\hline Terms of Trade & 0.9846 & 0.6120 & 1.6089 & 0.129 \\
\hline Human Capital & 3.5268 & 1.5144 & 2.3289 & 0.034 \\
\hline Investment in Transportation Sector & -0.9355 & 0.4177 & -2.2401 & 0.041 \\
\hline Constant & -2.2680 & 3.7830 & -0.5995 & 0.558 \\
\hline
\end{tabular}

Table 4 describes the shortrun estimates of model in which the Cointegrating term (COINTEQ01) 
confirms the convergence of equilibrium from short-run to long-run with a statistically significant value having 61 percent adjustment per anum.

Table 4: ARDL Shortrun results

\begin{tabular}{|c|c|c|c|c|}
\hline Variable & Coefficients & $\begin{array}{c}\text { Standard } \\
\text { Errors }\end{array}$ & t-Statistic & Probability \\
\hline D(TRADE(-1)) & -0.470 & 0.185 & -2.540 & 0.02 \\
\hline D(AGRI) & 0.044 & 0.066 & 0.659 & 0.52 \\
\hline D(AGRI (-1)) & -0.178 & 0.073 & -2.429 & 0.03 \\
\hline D(AGRI (-2)) & -0.076 & 0.077 & -0.989 & 0.34 \\
\hline D(AGRI (-3)) & 0.148 & 0.078 & 1.905 & 0.08 \\
\hline D(MANU) & 0.274 & 0.099 & 2.781 & 0.01 \\
\hline D(MANU (-1)) & -0.067 & 0.105 & -0.637 & 0.53 \\
\hline D(MANU (-2)) & 0.040 & 0.098 & 0.414 & 0.69 \\
\hline D(MANU (-3)) & -0.238 & 0.079 & -3.004 & 0.01 \\
\hline D(SERV) & -0.144 & 0.143 & -1.004 & 0.33 \\
\hline D(SERV (-1)) & 0.017 & 0.110 & 0.157 & 0.88 \\
\hline D(SERV (-2)) & 0.090 & 0.126 & 0.712 & 0.49 \\
\hline D(SERV(-3)) & -0.084 & 0.058 & -1.459 & 0.17 \\
\hline D(TOT) & 0.021 & 0.212 & 0.099 & 0.92 \\
\hline D(HUMCAP) & -4.338 & 3.544 & -1.224 & 0.24 \\
\hline D(HUMCAP(-1)) & -4.170 & 3.387 & -1.231 & 0.24 \\
\hline D(TRANS) & -0.152 & 0.087 & -1.751 & 0.10 \\
\hline D(TRANS (-1)) & 0.109 & 0.111 & 0.982 & 0.34 \\
\hline D(TRANS (-2)) & 0.257 & 0.107 & 2.395 & 0.03 \\
\hline D(TRANS (-3)) & -0.119 & 0.082 & -1.447 & 0.17 \\
\hline CointEq(-1) & -0.614 & 0.181 & -3.395 & 0.00 \\
\hline
\end{tabular}

For the validation of econometric results, Jarque - Bera test, Ramsey RESET and CUSUM \& CUSUM of squares have been utilized which shows that the econometric model is dynamically stable and correctly specified while residuals are normally distributed.

Figure 1: Jarque-Bera - Normality Test

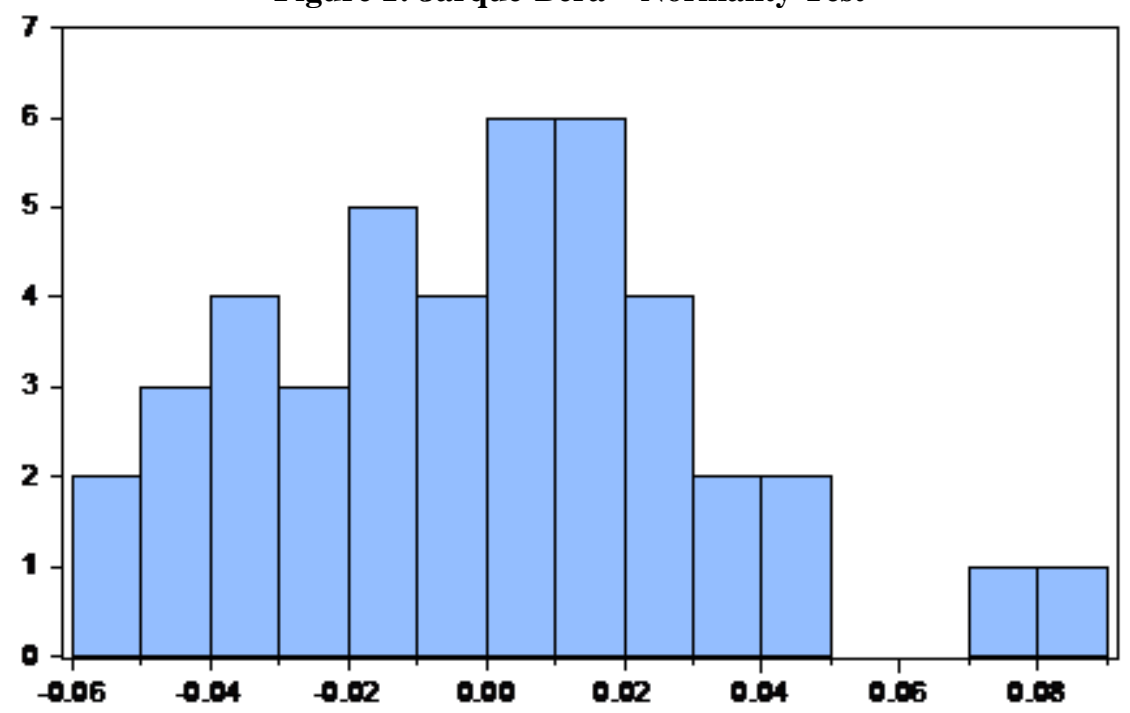

Table 5: Model Specification test - Ramsey RESET test

\begin{tabular}{|c|c|c|c|}
\hline Statistics & Value & Degree of freedom & Probability Values \\
\hline t-statistics & 0.0728 & 14 & 0.940 \\
\hline F-statistics & 0.0053 & $(1,14)$ & 0.940 \\
\hline
\end{tabular}


Figure 2: Dynamic Stability - CUSUM test

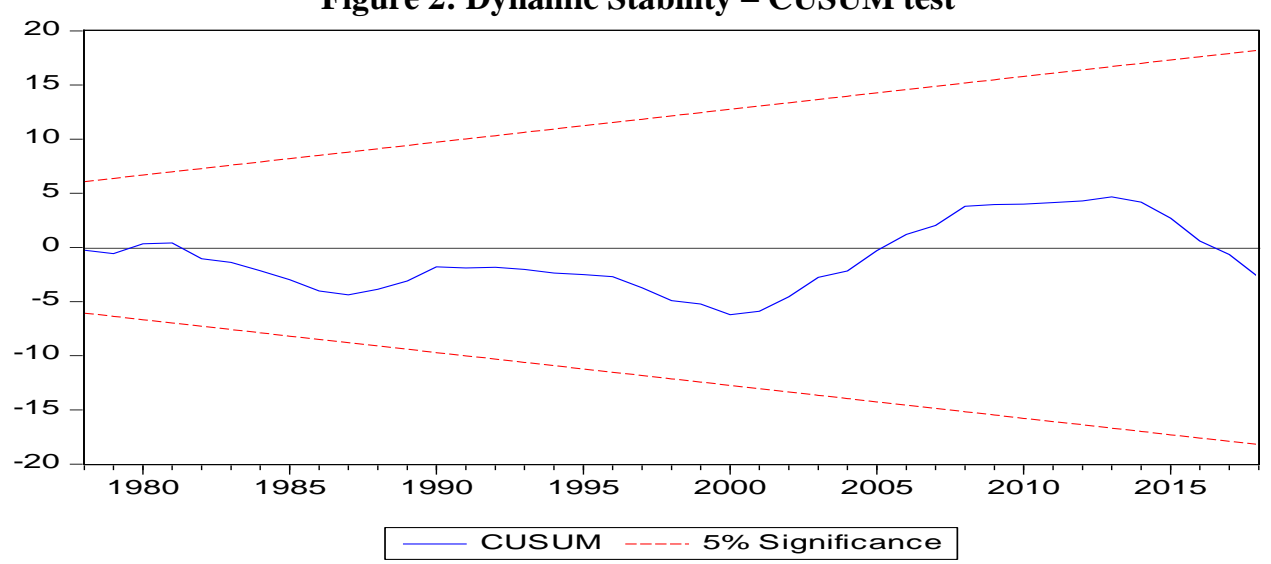

Figure 3: Dynamic Stability - CUSUM of Squares

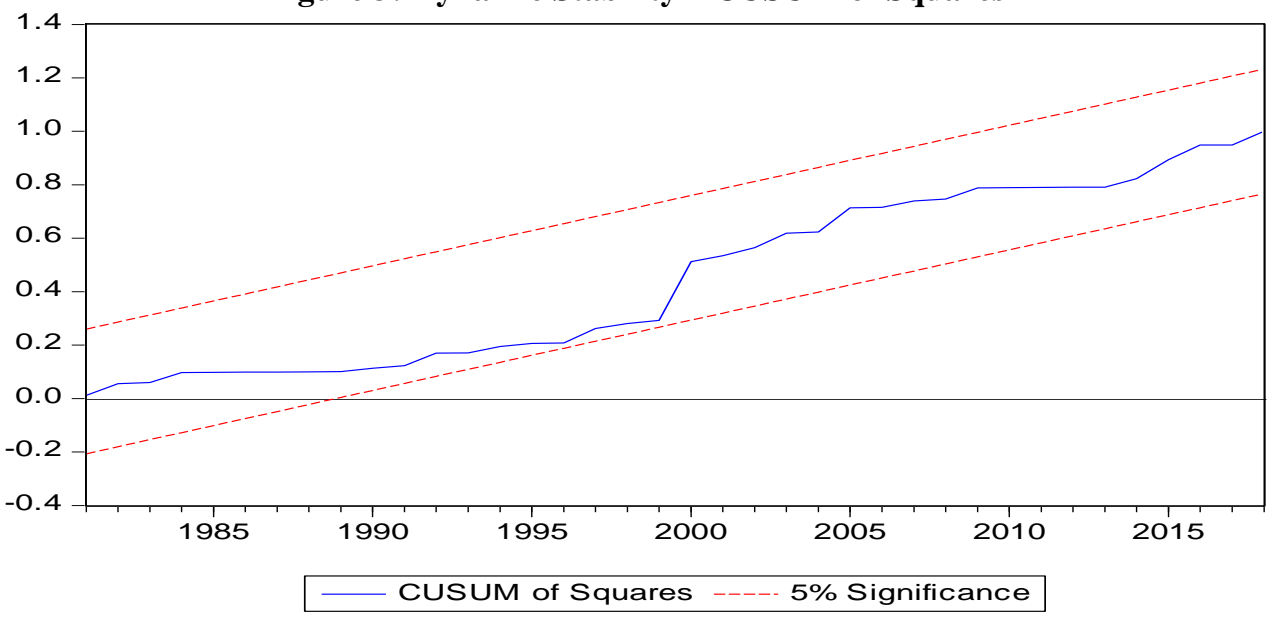

\section{Conclusion and Policy Implications}

Investment in several important sectors of the economy plays vital role in expanding trade of Pakistan in the longrun. The study considers the various forms of Investments like Agricultural Investment, Industrial Investment, Services Investment etc. So, the present study is organized to proble the influence of sectoral investment on trade of Pakistan using time series data over the period from 1972 to 2018. Longrun or Cointegrating relationship is inspected through ARDL Bound testing approach, long-run and short-run results are estimated using the ARDL method. For diagnostic statistics, the normality test is applied for checking normality residuals, the Ramsey RESET test is utilized for exploring correct model specification of the model and the dynamic stability of the model is examined through CUSUM and CUSUM of Squares. It is found that Investments in the Agriculture \& Manufacturing sectors, Terms of Trade and Human Capital are found as increasing factors for exports of Pakistan while investments in Services \& Transportation sectors are negatively associated with exports of Pakistan.

The results of Diagnostic statistics highlights that the Econometric model is not having problem of Normality as well as the model is correctly specified and the model is also dynamically stable. Based on econometric results, it is suggested that investments in manufacturing and agriculture sectors should be enhanced through low interest rates or by providing opportunities to the private sector so that it may lead to higher growth and exports. There is also need to invest in training and health of people (human beings) so that it may increase the productive capacity of the community for the trade of Pakistan.

\section{References}

Abdul, W., \& Jawaid, S. T. (2010). Inward foreign direct investment and aggregate imports: time series evidence from Pakistan. University Library of Munich, Germany. 
Asirvatham, J., Rasiah, R., Thangiah, G., \& Naghav, N. (2017). Impact of Foreign Direct Investment, Imports and Tariff Deregulation on Exports among Pioneering Asean Members: Panel Data Analysis. International Journal of Business and Society, 18(1).

Bhatt, P. R. (2013). Causal relationship between exports, FDI and income: The case of Vietnam. Applied Econometrics and International Development, 13(1), 161-176.

Bhutto, N. A., Daudpota, A. K., Shahzad, R., Tabassum, M., \& Malik, A. (2008). The Impact of Foreign Direct Investment (FDI) on Pakistan Exports: An Empirical Analysis.

Cuyvers, L., Soeng, R., Plasmans, J., \& Van den Bulcke, D. (2008). The impact of inward foreign direct investment on international trade in Cambodia.

Goh, S. K., \& Tham, S. Y. (2013). Trade linkages of inward and outward FDI: Evidence from Malaysia. Economic Modelling, 35, 224-230.

Goran Vukić Occasional Paper No. 27 June 2006 Impact of foreign direct investment on Croatian manufacturing exports.

Goswami, C., \& Saikia, K. K. (2012). FDI and its relation with exports in India, status and prospect in north east region. Procedia-Social and Behavioral Sciences, 37, 123-132

Hailu, Z. A. (2010). Impact of foreign direct investment on trade of African countries. International Journal of economics and Finance, 2(3), 122-133.

Kutan, A. M., \& Vukšić, G. (2007). Foreign direct investment and export performance: empirical evidence. Comparative Economic Studies, 49(3), 430-445.

Marchant, M. A., Saghaian, S. H., \& Vickner, S. S. (1999). Trade and foreign direct investment management strategies for US processed food firms in China. The International Food and Agribusiness Management Review, 2(2), 131-143.

Nishitateno, S. (2013). Global production sharing and the FDI-trade nexus: New evidence from the Japanese automobile industry. Journal of the Japanese and International Economies, 27, 64-80.

Pain, N., \& Wakelin, K. (1997). Export performance and the role of foreign direct investment. The Manchester School, 66(S), 62-88.

Pain, N., \& Wakelin, K. (1998). Export performance and the role of foreign direct investment. The Manchester School, 66(S), 62-88.

Pourshahabi, F., Salimi Soderjani, E., \& Mahmoudinia, D. (2013). Panel Causality Relationship among FDI and Trade (Evidence from 16 Advanced Europe Countries). Iranian Economic Review, 17(1), 115-133.

Rafat, M. (2017). The Interactive Relationship between Regional Trade Integration and Foreign Direct Investment. Iranian Economic Review, 21(4), 809-828.

Rahman, M. Z. (2011). An empirical study on the relationship between foreign investment and international trade in Bangladesh. International Journal of Financial Research, 2(2), 33.

Selimi, N., Reçi, K., \& Sadiku, L. (2016). The Impact of Foreign Direct Investment on the Export Performance: Empirical Evidence for Western Balkan Countries. ILIRIA International Review, 6(1).

Stojčić, N., \& Orlić, E. (2016). Foreign Direct Investment and structural transformation of exports. Ekonomska misao i praksa, (2), 355-378.

Wongpit, P. (2006). Impact of FDI on manufacturing exports in Thailand.

Zhanje, S. (2018). Export performance and foreign direct investment in Zimbabwe: An ARDL Approach. International Conference on Public Administration and Development Alternatives (IPADA). 